\title{
INDUSTRIAL CULTURESCAPE: TERRITORY AS CONTEXT
}

\author{
ANA SCHMIDT \\ Provincial Government of Biscay, Spain \\ National University of Distance Education (UNED), Spain
}

\begin{abstract}
The European Landscape Convention has contributed to understanding landscape as an important component of collective well-being and highlighted the need to manage the entire territory as a landscape. The Nervion estuary, Abra Bay and mining area deserve to be considered an urban cultural landscape, because of their heritage value and singular beauty. The landscape of the Nervion and Abra has developed over time, above all, throughout the period of industrialisation. Restoring the industrial heritage landscape, such as the old mining railways, may bring the existing cultural landscape closer to the environment of the people who live in these areas. This study categorises the heritage elements and traces of the Orconera mining railway, in order to understand the current landscape and determine a proposal for action to preserve them and restore the mining railway line as a green infrastructure. In this case, preservation as a sustainable landscape means proposing a new use for it as cultural landscape and tourism. Although industrialisation has had a serious impact on the development of the whole Bilbao metropolitan area, the mining-industrial heritage includes sites that are somewhat unexplored and overlooked by urban policies.

Keywords: cultural landscape, cultural tourism, industrial cultural heritage, industrial tourism, mining railways.
\end{abstract}

\section{INTRODUCTION}

In the study we carried out on the Nervion Estuary, its banks, the Abra Bay and the mining area within the Greater Metropolitan Area of Bilbao, we found a landscape that rightfully comes under the description of cultural landscape, as per this definition in the 1992 UNESCO Convention on Cultural and Natural Heritage. The most significant feature of the World Heritage Convention is that it links together in a single document the concept of nature conservation and the preservation of cultural properties. To be included in the World Heritage list, sites must be of outstanding universal value and meet at least one of ten selection criteria. Although the Orconera mining railway and the Bodovalle open pit mine might not achieve an "universal value" as to "transcend national boundaries", it meets at least one criteria: the remaining infrastructures are an outstanding example of a crucial period of the industrial development in the Basque Country and Europe.

The estuary has been shaped as a landscape of symbolic meanings, in which the urban effects of overcoming the industrial crisis of the 20th century and the formation of Bilbao as a services capital are now in conflict, with spectacular urban marketing works around the operations in the Abandoibarra district, all in contrast to a very powerful industrial past, of which few vestiges remain and that current urban planning seems to want to forget. Moreover, urban sprawl itself contributes to the profound transformation of the landscape, creating many areas where the rural and urban are interwoven in a confused pattern. While the administration has boosted the recovery of the municipality of Bilbao as a service centre, its suburbs feature illegal constructions, conflicts over land use and complex motorway links that leave a lot of "empty land" and disused spaces with waste dumping, etc. As a result of this process, the landscapes on the left bank have altered and new, hybrid, complex landscapes have been created, which are devoid of character and are even banal at times. For 
this reason, rethinking the region of the former mining area of Biscay, as we propose, and looking for systems to revive the industrial heritage landscape, such as the old Orconera mining railway, means recovering understanding of a past that made a special mark on the configuration of the Bilbao metropolitan area and is part of the collective identity of its inhabitants.

It is important to resort to reading and interpreting this landscape through visual representations of it by artists. The estuary and the Abra have been the subject of a number of pictorial and literary interpretations by great masters of art. The painters who have depicted its landscapes include: Guinea, Morera, Regoyos, Arteta, Gal, Párraga, Losada, Arrúe, etc. The writers who have described and incorporated them into their narratives include: Zunzunegui, Unamuno, Basterra, Blas de Otero and Aresti and contemporary writers, painters and photographers include: Pinilla, Reché, Lazkano, Quincoces, Basílico, Carlos Cánovas, etc. All these visual and literary representations add value and heritage content to the landscape, even more so when, from very varied fields and different epistemological approaches, the reductionism which the supposedly objective study of the landscape involves is questioned [1].

\section{THE CONTRIBUTION OF ARTISTS TO READING AND INTERPRETING THE} LANDSCAPE OF THE NERVION ESTUARY, ABRA BAY AND MINING AREA

Bilbao, its estuary and the mining area are places that have inspired many poets: Basterra, Unamuno, Aresti, Ossa Echaburru, Pinilla, Zunzunegui, etc. It is a scene of curiosity. It offers a special landscape: The urban sprawl appears wedged between the mountains and the estuary. Today, if the urban landscape is not badly run down, it actually seems to be, as everywhere there are obvious traces and signs that the industrial crisis of the past years left numerous scars. An analysis of the interpretations of the landscape from different cultural agents through their works provides us, on the one hand, with an overview of the historical evolution of the landscape, of its most significant moments, and on the other, it focuses our view on certain spaces, which acquire greater symbolic significance for their inhabitants than others. All these visual and literary representations add value and heritage content to the landscape, even more so when, from very varied fields and different epistemological approaches, the reductionism which the supposedly objective study of the landscape involves is questioned.

The need to incorporate explicitly subjective sources, such as literature, film and painting into landscape research seems beyond doubt. In this sense, visual and literary images are of interest for landscape analysis, not only as works of art in their own right, which they are and for the heritage values that they contribute, but also because they synthesise reality, serve as a reference to describe it and facilitate the knowledge that society has forged about it. These representations also act as privileged resources for analysing the value attributed to different spaces, without forgetting the role played in this assessment by the artists' mechanisms for filtering perception and the dominant world views at the time they were painted or described. Certain sceneries are repeated, being configured as places that define the mental image of a region, while others remain virtually unnoticed.

Landscape painting of the 19th and 20th century and contemporary photography literally offer us masterful brush strokes of the historical evolution and formation of the Bilbao metropolitan area. The paintings of the early 20 th century bear witness to the past strength of industrialisation and the spaces that made it possible, the banks of the estuary and the mining area [2]. The estuary painted in the late 19th century shows very clear skies, mountains cut clear against the sky, crops, groves, isolated houses and farmhouses. A painting by Anselmo Guinea (1854-1906) from that period is of extraordinary luminosity, an idyllic landscape. 
The painting is dated shortly before the massive exploitation of iron mines, the transformation of the old foundries into powerful blast furnaces, the construction and repair of ships, the founding of shipyards and the development of the port of Bilbao appeared at the heart of this peaceful landscape. If we compare Anselmo Guinea's painting with the later works of Ignacio Ugarte (1858-1914), the estuary and its surroundings undoubtedly take on darker hues, although still not as much as Jaime Morera's black paintings (1854-1927): a gloomy, almost threatening world in which only the bright fires of the blast furnaces stand out. Later, Gabriele Basilico showed us the industrial dismantling operations in all their starkness.

If we take a quick tour through paintings and photographs, we can clearly see the periods that mark the evolution of the metropolitan area: the industrial launch and boom from 1880 to 1970 , the crisis and onset of industrial decline from 1970 onwards and, from 1990 onwards, the slow recovery and change of model through industrial restructuring strategies and a policy of major projects that did not always respect historical memory and collective identity.

The main concern regarding current planning actions in the estuary area is primarily aimed at its inclusion within the post-modern urban schemes, but we believe that these objectives do not have to ignore values and landscape features of the past that deserve to be preserved

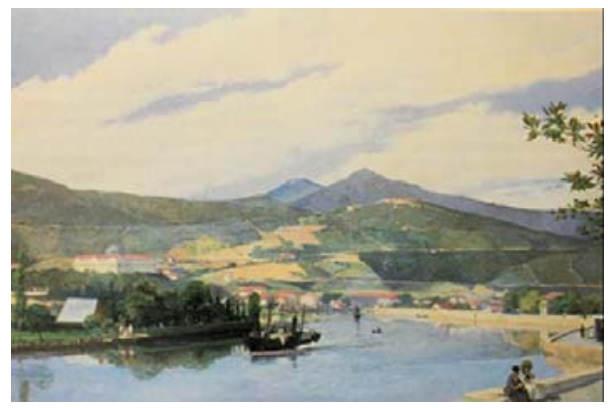

Figure 1: Guinea, A., Ribera de Deusto (Deusto river bank), private collection, 1878 .

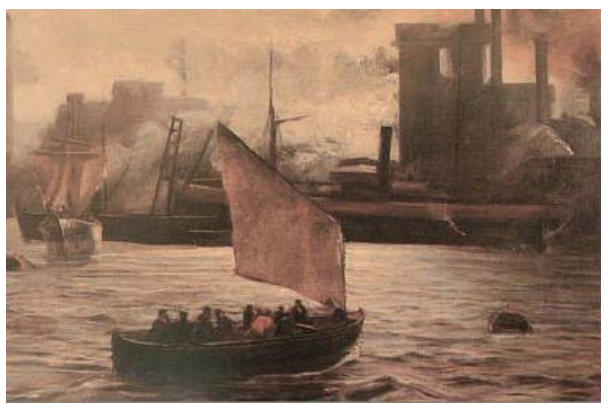

Figure 2: Ugarte, I., Altos Hornos y la Ría (Altos Hornos factory and the Estuary), private collection, 1902.

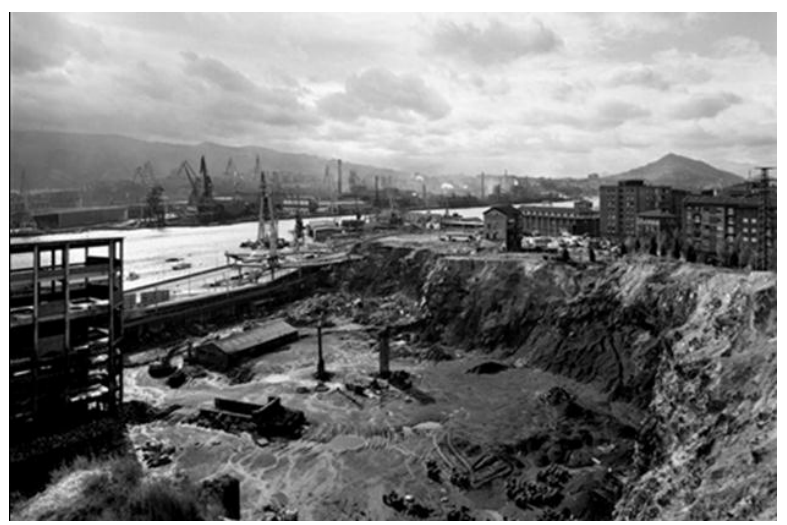

Figure 3: Basílico, G., Bilbao, Bilbao-Metropoli 30 (Metropolitan Bilbao), 1993. 
and highlighted. This is precisely what we intend to contribute with our work and the use of forms of approach stemming from the geography of perception that give special value to visual representations and literary descriptions and, in all cases, to the forms of collective images that facilitate the identification of citizens with the place in which they live.

The estuary of Bilbao as an inland port has accumulated more pictorial and literary interpretations than other industrial landscapes. Its natural scenery and the effects on it of the economic and social changes linked to industrialisation and the social processes that accompany it have attracted historians, journalists, writers, painters and photographers, and, whatever the case, it provides an urban setting that is difficult to explain exclusively through history and conventional geographic-territorial analysis.

The metropolitan area that we see today has been profoundly modified by the most recent urban developments, while at the same time showing traces of its past and present: industrial wastelands, facilities that are disused or in decline, some of which have been renovated and residential types from different eras and social environments, together with recent replacement actions. Everywhere, there are clear traces and obvious signs of the scars left on the region by the industrial crisis of the 1970s and 1980s, together with recent replacement operations (Acería Compacta, Urban-Galindo, Metalquímica, etc.). The paintings of Inaki Bilbao, José María Lazkano and Alejandro Quincoces from the late 20th century bear witness to these mental images of an estuary in decline, with specific renewal projects juxtaposed seamlessly with the existing features of the past that have not finished transforming their perimeters into spaces for public use and enjoyment.

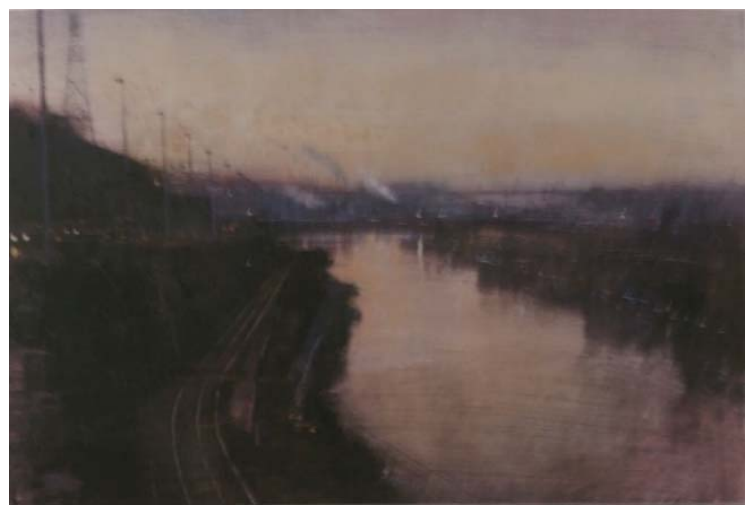

Figure 4: Quincoces, A., Anochecer (Dusk), 1998.

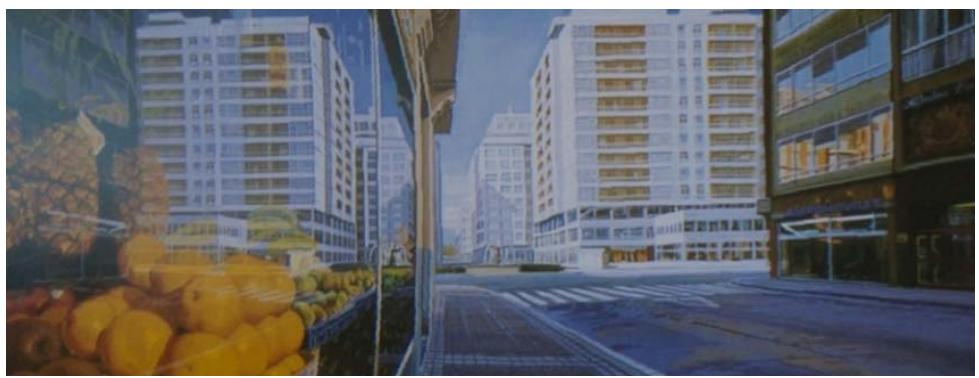

Figure 5: Reché, A., Campuzano, approx. 1995. 
The estuary has been shaped as a landscape of symbolic meanings, in which the urban effects of overcoming the industrial crisis of the 20th century and the formation of Bilbao as a services capital are now in conflict, where urban marketing policies are framed around the operations in the Abandoibarra district, in contrast to the industrial past, of which few vestiges remain. Quincoces's images, which reflect the abandonment and neglect of the industrial past, contrast with the splendour of Reché's paintings. On the other hand, it will be the illustrations and engravings from the late 19th century, especially in the magazine Ilustración Española y Americana, that devote a specific section to Biscayan mining and the Triano and Somorrostro area, showing the scenario of economic and technological development.

\section{CONSTRUCTION AND RECONSTRUCTION OF AN INDUSTRIAL LANDSCAPE} In the first third of the 19th century, the first attempts at economic revival were made, followed by the modern industrialization process in its phases. First, the boom and consolidation (1876-1930) and then expansion or second industrialisation (1950-1975), concluding with the end of this economic cycle, as the effects of the economic crisis around the third quarter of the 20th century (1975-1985) became apparent.

The first industry to be implemented from the mid-19th century was an industry of large factories - a major consumer of land - arising from the introduction of the latest technical developments in the traditional steel industry and the consequent massive exploitation of iron ore at the Somorrostro mine. This was soon joined by a booming shipbuilding industry. Due to their own needs, these activities occupied the river plains and provided the estuary with a manufacturing intensity, which put the Basque Country at the head of the state, diversifying the economic model with other activities, such as maritime transport, the electricity industry, the chemical industry, etc.

Around 1930, after the boom period and the modern consolidation process, a first approximation of the current metropolitan area of the estuary and Abra was now taking shape. It was structured around four morphologically and functionally differentiated zones: Bilbao, the industrial middle area, the mining area and the outer Abra area. Bilbao was the functional

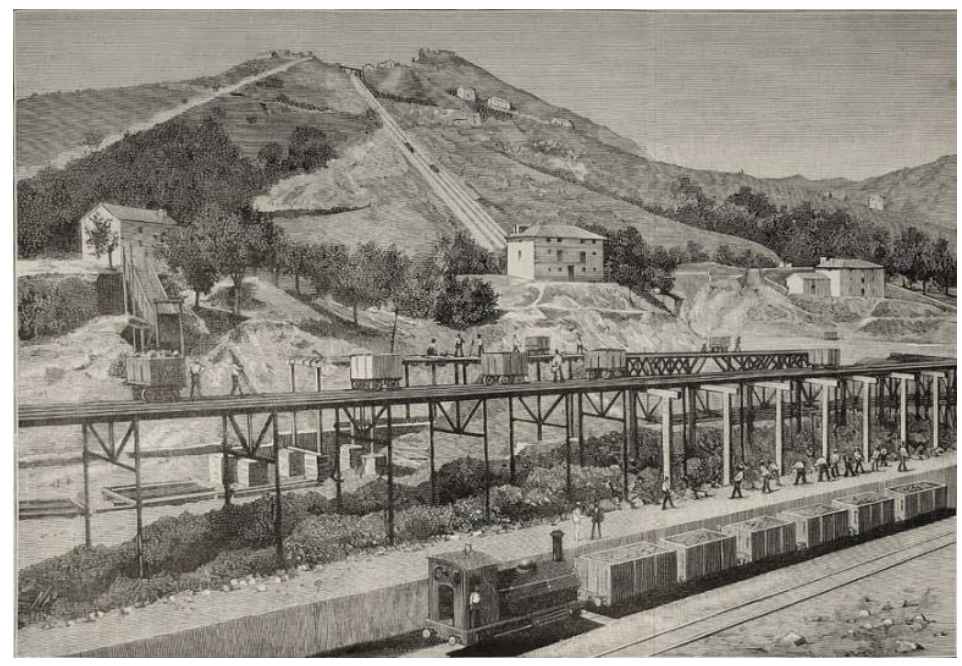

Figure 6: Minas de Somorrostro (Somorrostro mines (Bilbao). (Source: an engraving by Manuel Nao, La Ilustración Española y Americana, 1882.) 
centre, the driving force behind the transformation of the rural surroundings and the focal point of the road network. The industrial middle area consisted and still consists of the municipalities of Barakaldo and Sestao on the left bank and Erandio, Leioa and Deusto until its annexation in 1924 - on the right bank. It was characterised by a juxtaposition of residential and industrial buildings and port facilities, with industries occupying the flat lands of the estuary. The mining area was made up of small towns, such as La Arboleda, Trápaga, Ortuella and Abanto. The Abra area, which was basically residential and initially dedicated to bourgeois leisure, was made up of Portugalete and Santurtzi on the left bank, and Getxo on the right bank [3].

The first urban developments in this area were carried out at the end of the 18th century through the Ensanche (expansion) projects. The initial and most representative is that of Bilbao, drawn up by Alzola, Achúcarro and Hoffmeyer in 1876. They designed a new city, separated from the traditional area by the estuary. A belt of suburbs emerged around the expansion space, without prior planning. Bilbao city council proposed a new expansion, which would be finally carried out by Enrique Epalza in 1896. Later, in 1923, the regional planning of the entire estuary was undertaken. Ricardo Bastida designed the road connection scheme of the towns bordering Bilbao.

Since 1975, with the onset of the crisis and the subsequent two decades of uninterrupted decline, a series of projects and initiatives - investments in major infrastructures, economic promotion policies - were implemented for the metropolitan area, aimed at setting in motion a metropolitan regeneration process. These were a series of strategies that had already been tried out in other cities in the de-industrialisation process, such as Pittsburg and Baltimore. These were large urban projects that tried to physically and functionally transform the metropolitan area, converting unique, strategic spaces that had degraded or were occupied by obsolete activities. The conversion of Abandoibarra, a former industrial area within the city of Bilbao, laid the foundation stone for a number of public works projects in the search for revitalisation.

Since 1990, we have witnessed a process of economic regeneration and the formation of a new tertiary-based urban model. Since the 1980s, the services sector has partially compensated for the destruction of employment in the industrial sector. The deindustrialisation process will intensify the spatial hierarchy and social segregation between left and right bank, as it will be the municipalities on the left bank that will suffer job losses most severely and see a little development of tertiary activities due to the relocation of the resident population from the depressed areas on the left bank to the right bank. As a result, the average income of the metropolitan area was not evenly distributed. It decreased significantly on the left bank around 1980, while on the right bank it went up.

From the 1990s onwards, a number of economic regeneration strategies were initiated, basically based on three types of operations: regional and urban planning instruments, strategic planning and major urban and infrastructure operations.

The drafting of the Bilbao Land-use Plan, which began in May 1989, laid the foundations for this process. The plan recognised the situation of industrial decline and made a number of proposals for reviving degraded areas, such as Abandoibarra, Amezola and Zorrozaurre and abandoned mining areas such as Miribilla and El Moro. The proposals in the Land-use Plan coincided with the urban trends of the time (1980s), i.e. urban planning based on individualised projects and partial and fragmented works. In addition to the Inventory of Industrial Ruins, it was also responsible for drafting the Partial Metropolitan Bilbao Territorial Plan, the development of which was submitted in 1994 and finally approved more than ten years later (26 Sep. 2006). Its proposals focused on the restoration of degraded areas for tertiary and leisure activities. In 1989, the Strategic Plan for the Revitalisation of 
Metropolitan Bilbao was drawn up, which later served as the basis for the preparation of the Partial Territorial Plan. In addition, in 2001, Bilbao 2010: The Strategy was presented, which proposed converting Bilbao into a "global city".

Apart from strategic planning, it proposed the establishment of large transport and infrastructure projects for the regeneration of the metropolitan area (the construction of the outer harbour, a new airport terminal, construction of the metro and remodelling of the suburban railway, in addition to the comprehensive plan for the estuary and the Guggenheim Museum).

After decades of conversion, there was another recession in 1993, which led to the search for a third convergence at the start of the new century, i.e. convergence on $R \& D+i$, which, however, has not produced clearly positive effects on the economic system, which, at a regional level, translates into the continuation of the tertiary model initiated, but with a clear slowdown (Zorrozaurre).

To conclude, it should be pointed out that the regeneration operations have clearly turned Bilbao into a services capital, through the operations undertaken, such as Abandoibarra, Guggenheim, etc. However, actions in the industrial and mining areas have been scarce (Urban Galindo, Acería Compacta, etc.).

\section{REVIVING THE ORCONERA RAILWAY LINE: A PROPOSAL FOR PRESERVING THE IDENTITY OF THE LANDSCAPE}

The left bank of the Nervion estuary has been one of the largest industrial concentrations in Europe since the end of the 19th century and, with its cultural landscape, has contributed to shaping the identity of Basque society and the perception of it from outside. Its conversion and transformation into a metropolitan service area has had a profound impact on the management of the heritage of this collective memory. The urban development actions planned and carried out in recent decades on landscapes dedicated to industry and mining have rarely preserved the character of the surroundings. In all cases the focus has been on the reuse of unique buildings (Illgner Building).

"The most effective way to destroy people is to deny and obliterate their own understanding of their history" (George Orwell).

Landscape restoration cannot consist solely of reviving the primeval scenery of nature, forgetting that our landscapes are made up of an important cultural heritage resulting from human activity on nature. As a sustainable landscape practice, this proposal to restore the Orconera mining railways as a green infrastructure enhances the site's identity and meaning by protecting and maintaining this significant historic structure and cultural landscape as a unit. Territory can be recognised as heritage and legacy; it contextualizes the imprint of economic history on landscape. It is a territorial heritage, in which cultural identities can be found. It is a reading of culture and heritage in territorial terms. It is in this context that the historical knowledge of this place, the Nervion estuary and Abra Bay, is of interest, in which a clear cultural orientation towards the mining heritage can be seen. Sustainable landscape practices encourage cultural integrity and promote regional identity.

The Biscayan landscape was created based on obtaining a resource, iron: the foundries, shipyards, mills, needed silting work, the construction of buildings, mines, quarries and even forests. All of these elements are today cultural heritage, testimony of our history and architectural projects and urban and regional planning plans should include them in their proposals. In this research study, we propose the restoration of the old Orconera railway line, due to the fact that it provides the opportunity to explain history through a pedestrian route that starts from the urban area and goes into the mining area, as this mining railway is the only one that climbs to an altitude of $200 \mathrm{~m}$ above sea level with a constant slope [4]. In order 
to make a proposal to restore and treat the landscape, the various stages of the configuration of the mining railway line and its components have been researched. A first approach to the various stages of configuring Biscayan mining also provides us with a first approach to the stages of the construction process of the railway itself, the traces of which have been depicted in the territory and which remain in some cases.

We have been able to distinguish the first stage, which began in 1877 with the opening of the railway and lasted until 1910. This stage coincided with the period of greatest production of iron ore, which was obtained in the open air, with simple mechanical means, as it was located on the surface [5]. During this period, tunnels and clearings were built to make it possible to reach the mining reserves by means of a constant slope. Granada station was used as an interchange station and the sloping planes of Matamorros made it possible to haul the material from higher elevations. Loading docks were installed in the inland port, in total 5 , for shipping and exporting the material. The gradual depletion of ore meant the introduction of a second system from 1910 to exploit the remaining mining material, in order to treat the iron carbonates and minerals associated with clays and mud: calcination furnaces, mineral washing systems, settling basins and the aerial tramway up to Campomar. The most important mineral washing systems in this era were the one at Campomar and the one in the Granada ravine.

1950 marked a new milestone in the landscape of iron mining, in mining railways and, specifically, in the Orconera mining railway. The depletion of ore not only brought with it the introduction of new techniques to exploit the mountain. Biscayan mining in the 1950s was weighed down by two problems: low production and the scarcity of iron-rich minerals, white minerals. These data demonstrated that the future of Biscayan mining lay in carbonates. The most important reserves were located in Bodovalle. The mining of existing carbonates in the subsoil led to the creation of the underground galleries, that were normally made with the ore itself, which was quite resistant. The room-and-pillar system was used, similar to the one that had traditionally been used, but with larger dimensions. Large chambers were made, where there were bags of ore, supported by buttresses or pillars of ore and rock in the form of columns and load-bearing walls. Increasing productive capacity meant introducing major changes to traditional Biscayan mining, characterised by isolated, small-scale mining sites and properties, although there were also larger companies. At that time, i.e. from 1950 onwards, large companies were set up, which provided the basis for achieving the necessary means and infrastructures to develop the deep masses of carbonates located, in some cases, up to 300 metres below sea level. The Concha II and Bodovalle vein in Gallarta, closed since 1993, was the result of this last iron mine in Biscay. Apart from its historical value, it stands out for its size. In principle were two types of extraction: surface/open-pit mining and underground mining in underground galleries; although during the final years only underground work was carried out, as the surface ore had been exhausted.

Both open-pit and underground mining formed an outstanding industrial cultural landscape, fundamental elements for understanding the industrialisation process in the Basque Country. This research project aims to restore the railway line from the Retuerto district, as a landscape and heritage route, showcasing, on the one hand, the panoramic views and surrounding hills, as well as the metropolitan area itself and the possible integration of the route into the urban fabric as a recreational space and, on the other, its heritage qualities, through the most important existing vestiges in the region that explain the history of mining and mining railways, such as the tunnels and mineral washing system at Matamorros, ending at the Bodovalle open pit mine and underground galleries. 


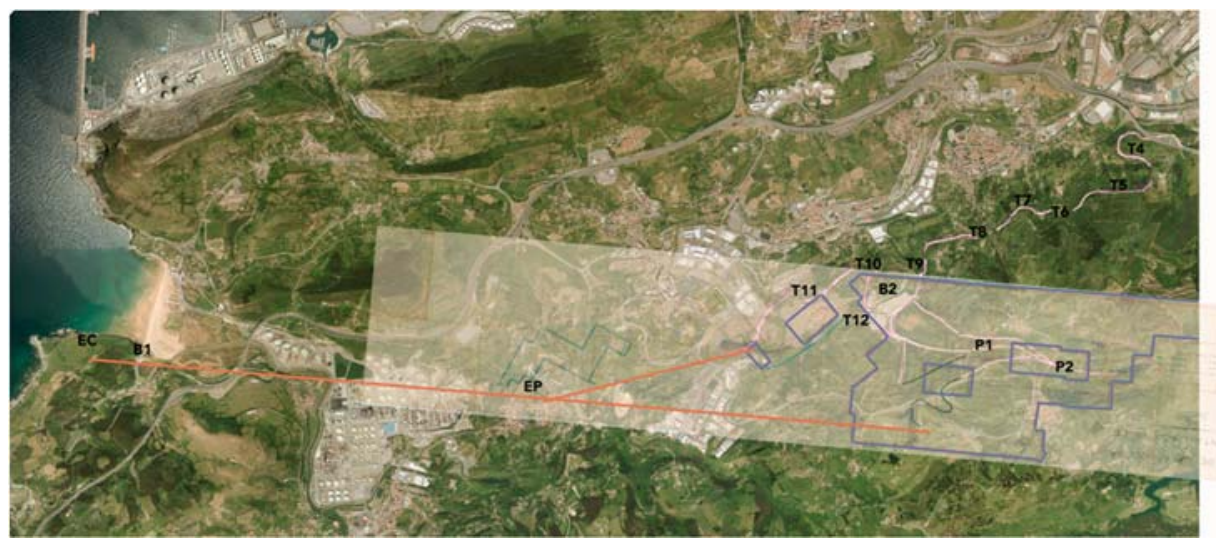

Figure 7: Overlay of current orthophoto and plan of mines in 1920 to obtain layouts of the Orconera railway line as per the periods indicated.

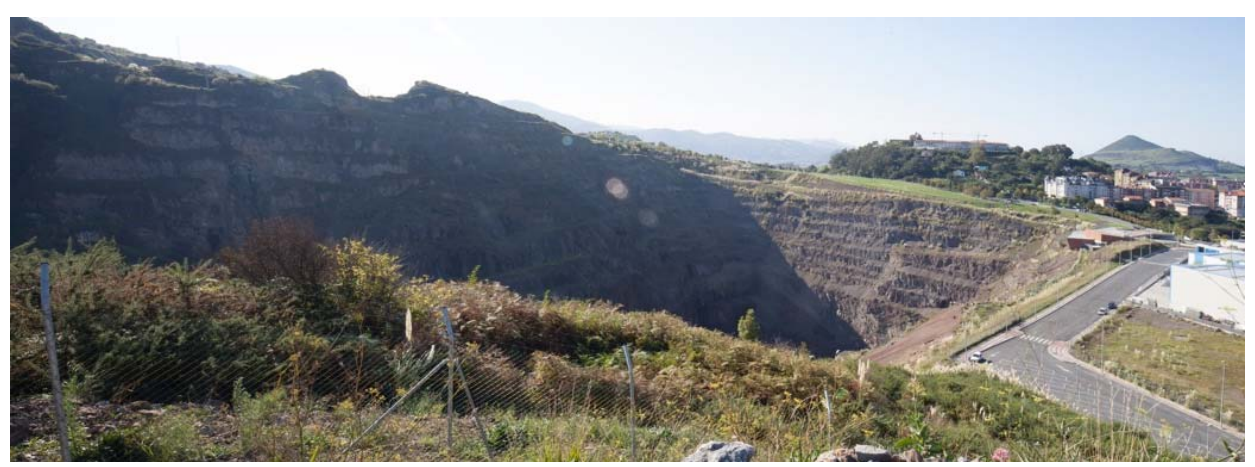

Figure 8: Current photo of the Bodovalle open pit mine made in 1959.

However, it is not only a question of showcasing elements that still exist that bear witness to recent history, but also of making it possible for the public to enjoy these routes through their integration into the urban fabric and landscape.

Searching for systems to restore the industrial heritage landscape, such as the old mining railways, the first mobile landscapes, means rescuing a resource, among other things, because of its implications when generating endogenous development processes [6]. Obviously, constructed material elements built are more identifiable, such as mineral washing systems, chimneys, industrial installations, etc. However, the routes themselves, their overlapping in the city, allow us to understand the history and functioning of industry in its context, as a result of which they become part of the set of heritage values of the place. In our case, the trace created by the old mining railways begins in the metropolitan area, ending up in the mining area, more specifically, in the Bodovalle open pit mine, offering the opportunity to integrate the landscape, understanding the rural environment in continuity with the urban environment. The Orconera railway trace is the only one of the mining area that still exists entirely and is identifiable as such and provides a physical access from the Metropolitan Area of Bilbao to the Bodovalle open pit mine. During the assessment and investigation process 
we have engaged relevant local stakeholders (Basque Country Mining Museum and Basque Association of industrial heritage and public works) through surveys and interviews to evidence that the proposal fits the site potential to become an acknowledged sustainable tourism destination.

\section{FINAL REMARKS}

This study shows how visual and literary representations add value and heritage content to the landscape. The aim is to analyse the values of landscape, its symbolic nature, incorporating the world of perceptions and sensations of the various artistic contributions. In our case, industrialisation and its forerunner, mining, have left an imprint that has an essential value as a testimony to the past. At present, the construction of the cultural landscape transcends mere links with the monumental to be perceived from a transversal perspective: it shapes the cultural identity of peoples and is essential for understanding the notion of territory. In this sense, it is essential to showcase the footprints in the landscape of the industrial and mining past as elements of collective identity. The route of the old Orconera railway, the only one that reaches a height of $200 \mathrm{~m}$ and therefore offers extraordinary views over the metropolitan area and the Abra, as well as the Bodovalle open pit mine, as the final point of this route and a unique testimony to the last stage of Biscayan mining, has been chosen as a specific example for the proposal.

\section{ACKNOWLEDGEMENTS}

I would like to thank Dr. Manuel Antonio Zarate Martín, accredited and honorary professor of the Department of Geography at the National University of Distance Education (UNED) and director of the Culturpais research group, for his critical review of this research work.

I would also like to thank the following institutions for their cooperation:

- Basque Country Mining Museum;

- Biscay Architectural Heritage Committee of the Basque-Navarre Official College of Architects;

- Provincial Historical Archive of Biscay;

- Basque Railway Museum.

\section{REFERENCES}

[1] Zárate Martín, A. et al., Paisaje, sociedad y cultura en geografía humana, Editorial Universitaria Ramón Areces: Madrid, 2011.

[2] Zugaza Miranda, M. et al., La ría: imagen y visión de un paisaje mercantil, Museo de Bellas Artes de Bilbao: Bilbao, 1993.

[3] Beascoechea Gangoiti, J.M. et al., Los orígenes de una metrópoli industrial: la ría de Bilbao, Fundación BBVA: Bilbao, 2001.

[4] Hormaechea Hernaiz, A.M., Ferrocarriles en Vizcaya, 1855-1913, Universidad de Deusto: Bilbao, 1995.

[5] Monteiro, M., La California del hierro: las minas y la modernización económica y social de Vizcaya, Beta: Bilbao, 2005.

[6] Pardo Abad, C.J., Sostenibilidad y turismo en los paisajes culturales de la industrialización. Arbor, 193(785): a400, 2017. http://dx.doi.org/10.3989/arbor.2017. $785 \mathrm{n} 3006$. 